https://doi.org/10.37208/tgn27309

\section{Increased observations of comma butterflies in Glasgow Botanic Gardens and south-west Scotland}

\section{C.J. McInerny}

School of Life Sciences, University of Glasgow, Glasgow G12 8QQ

E-mail: chris.mcinerny@glasgow.ac.uk

The comma butterfly (Polygonia c-album) has a long history in Scotland, being present in southern areas before a decline during the early 19th century that resulted in its extinction; this loss reflected a contraction in range across the U.K., where the species became rare and localised (Thomas \& Lewington, 2010). However, since the early 20th century, the trend reversed with the comma increasing its British distribution. This resulted in a re-colonisation of Scotland, with individuals observed throughout the south and central parts of the country, particularly in the east, and fewer in the west and north (Futter et al., 2006; Sutcliffe, 2009; NBN, 2020). The underlying reasons for these dramatic fluctuations in the species' fortunes are not understood, although climate change, resulting in milder winters, is thought to have played a role in the more recent re-colonisation (Thomas \& Lewington, 2010).

The species was first observed in the Glasgow area during 2007, being found at Mugdock Country Park, Milngavie, just north of the city (Sutcliffe, 2009). Several commas were also noted during the same year in South Lanarkshire at Motherwell, Hamilton and East Kilbride (Hancock, 2008). Subsequently, it has been seen to the south and the east of Glasgow each year, with increasing numbers in the city from 2017 , and recorded even further north and west to Bute and Kilcreggan, both Argyll \& Bute, Gourock, Inverclyde, and Loch Lomond, Stirlingshire (Fig. 1).

The comma was first detected in Glasgow Botanic Gardens when one was seen next to the Kibble Palace on 20th March 2016 (S. Shanks, pers. comm.). The next was observed on 14th April 2019 in the medicinal/herbal garden near to common hop (Humulus lupulus), a food plant, though no caterpillars were subsequently found. In April 2020 three commas were found on a clear-felled south-facing slope in the Arboretum next to the River Kelvin (Fig. 2). The first was observed on 16th April, with others noted on 18th and 21st April. Digital photographs revealed that these were three different individuals. That all of these five butterflies were present early in the season, during March and April, suggests that they had over-wintered nearby; adult commas hibernate on trees with their cryptic shape and colouration offering excellent camouflage.

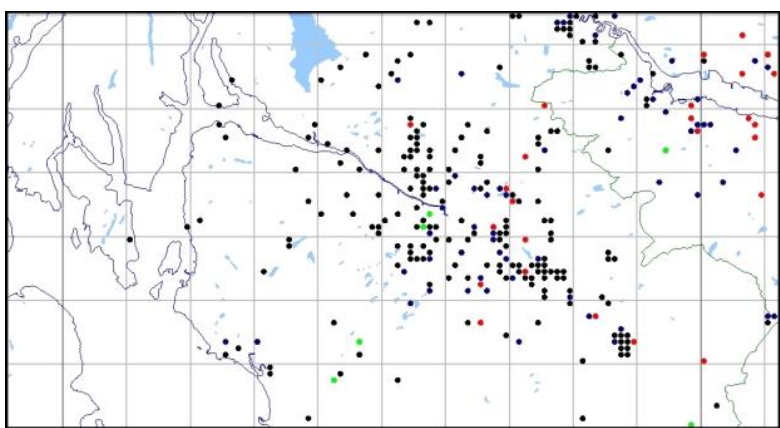

Fig. 1. Map illustrating the colonisation by the comma (Polygonia c-album) butterfly of the Glasgow area and southwest Scotland. Black dots $(\bullet)$ indicate records 2015 to 2019, blue dots (•) 2010 to 2014, red dots (•) 2005 to 2009, yellow dots ( ) 1995 to 2004, green dots ( $)<1995$. Grid $=10 \mathrm{~km}$. Data and mapping by Scott Shanks (Glasgow \& South West Scotland branch of Butterfly Conservation).
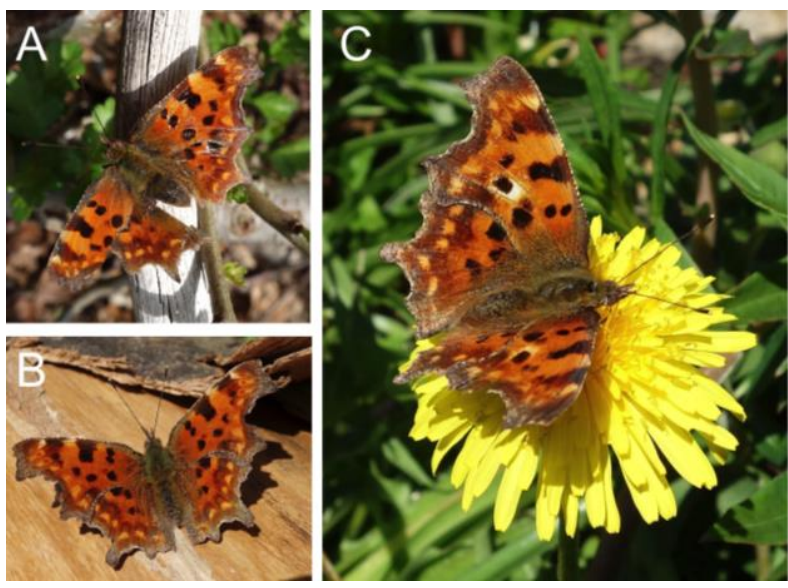

Fig. 2. Comma (Polygonia c-album) butterflies, Glasgow Botanic Gardens, Scotland, April 2020. Forewing length ca. $25 \mathrm{~mm}$. Three different individuals were observed in the same area near the River Kelvin: (A) on 16th, (B) on 18th, and (C) on 21st April 2020. (Photos: C.J. McInerny)

The three commas in 2020 were observed in a restricted area of the slope, alongside small white (Pieris rapae), orange-tip (Anthocharis cardamines) and peacock (Aglais io) butterflies. Each behaved territorially, chasing and competing with the peacocks, suggesting that if mates were found that they would reproduce in the vicinity. Suitable food plants for the larval stage, such as common nettle (Urtica dioica), goat willow (Salix caprea) and downy birch (Betula pubescens), are all present nearby.

This increase in observations of commas in Glasgow Botanic Gardens reflects the colonisation of the area and region by the species (Fig. 1). Others have been observed nearby in Glasgow since 2017, with records from Kelvingrove Park, Partick, the Kelvin Walkway, Ruchill Park and Dawsholm Park/Garscube Estate. It will be fascinating to see if this increase continues in the future, and if evidence of local breeding is discovered in the city, through the presence of eggs or larvae. 
I acknowledge the very helpful assistance of Scott Shanks, and the Glasgow \& South West Scotland branch of Butterfly Conservation, in providing many of the records summarised in this Short Note, and for creating the map shown in Fig. 1.

\section{REFERENCES}

Futter, K., Sutcliffe, R., Welham, D., Welham, A., Rostron, A.J., Mackay, J. et al. (2006). Butterflies of South West Scotland. Argyll Publishing, Glendaruel.

Hancock, L. (2008). Comma Polygonia c-album L. at Chatelherault, Hamilton. The Glasgow Naturalist 25(1), 99-100.

National Biodiversity Network (NBN) Atlas (2020). http://www.nbnatlas.org Accessed 17th May 2020.

Sutcliffe, R. (2009). Recent changes in the distribution of some Scottish butterflies and the arrival of new species in Scotland. The Glasgow Naturalist 25(2), 5-12.

Thomas, J. \& Lewington, R. (2010). The Butterflies of Britain and Ireland. British Wildlife Publishing, Gillingham, Dorset. 